\title{
Industrial Heat Treatment of Wood: Study of Induced Effects on Ayous Wood (Triplochiton scleroxylon K. Schum)
}

\author{
Emiliano Gennari (D, Rodolfo Picchio and Angela Lo Monaco *(D) \\ Department of Agriculture and Forest Sciences (DAFNE), University of Tuscia, Via S. Camillo de Lellis, \\ 01100 Viterbo, Italy; emiliano.gennari@unitus.it (E.G.); r.picchio@unitus.it (R.P.) \\ * Correspondence: lomonaco@unitus.it
}

Citation: Gennari, E.; Picchio, R.; Lo Monaco, A. Industrial Heat Treatmen of Wood: Study of Induced Effects on Ayous Wood (Triplochiton scleroxylon K. Schum). Forests 2021, 12, 730 . https://doi.org/10.3390/f12060730

Academic Editor: Miha Humar

Received: 6 May 2021

Accepted: 1 June 2021

Published: 3 June 2021

Publisher's Note: MDPI stays neutral with regard to jurisdictional claims in published maps and institutional affiliations.

Copyright: (c) 2021 by the authors. Licensee MDPI, Basel, Switzerland. This article is an open access article distributed under the terms and conditions of the Creative Commons Attribution (CC BY) license (https:// creativecommons.org/licenses/by/ $4.0 /)$.

\begin{abstract}
High-temperature treatment of wood is a useful method for improving certain physical characteristics, ensuring durability without biocides, and improving the performance of wood when exposed to degradation agents. This work aims to determine the effects induced by a heat treatment performed industrially on ayous wood (Triplochiton scleroxylon K. Schum) from Cameroon, through the study of the main physical and mechanical characteristics. The heat treatment at $215^{\circ} \mathrm{C}$ for three hours with a slight initial vacuum determined a reduction of the mechanical characteristics (compression strength $26 \%$, static bending $46 \%$, Brinell hardness $32 \%$ ) and some physical properties (dry density $11 \%$, basic density $9 \%$ ), while it improved the behaviour towards variations of environment moisture. The anti-shrinkage efficiency was $58.41 \pm 5.86 \%$, confirming the increase of the dimensional stability. The darkening $(\Delta \mathrm{E} 34.76)$, clearly detectable $\left(L^{*} 39.69 \pm 1.13 ; a^{*} 10.59 \pm 081 ; b^{*} 18.73 \pm 1.51\right)$, was supported almost equally by both the lightness parameter $\left(\mathrm{L}^{*}\right)$ and the $\mathrm{a}^{*}$ chromatic parameter. The data collected during the laboratory tests were then subjected to statistical analysis to verify correlations between the characteristics examined. Statistical differences were highlighted between each physical and mechanical properties of ayous wood modified or not.
\end{abstract}

Keywords: wood modification; mechanical properties; physical properties; anti shrinkage efficiency; colour; Cameroon

\section{Introduction}

The biological origin of woody materials makes them a valuable ally in reducing the environmental impact of human activities. Some intrinsic properties of wood, such as natural origin, nontoxicity, wide diffusion, and versatility of the material are the basis of the multitude of possible uses. In addition, the possibility of recycling primary wood products at the end of their life cycle, for example, to produce particle boards or similar secondary products, and finally, the valorisation of waste to produce energy from renewable sources (cascading), are characteristics that contribute to making wood an important resource against climate change and the rational and optimized exploitation of natural resources [1]. However, the natural origin of wood is associated with some drawbacks, among these the susceptibility to be altered by degradation factors is of great importance; in general, the most important degradation factors are UV, water and moisture, and biological organisms. The durability of wood is a characteristic variable among species that expresses the intrinsic ability to resist the action of degradation and decay agents. Often it is necessary to improve the natural durability of wood, particularly when it is used for outdoor purposes. Improving wood durability is achieved by treating wood with preservatives, however, these composites are often toxic, with a high environmental impact and high cost. There are alternatives to prevent degradation and decay; these are different modification processes classified into: chemical processes, thermo-hydro-mechanical processes, electromagnetic processes, and other types less common and developed. Among them, wood thermal modification processes have been extensively studied by researchers over the past decades, an activity that has been confirmed in the market with an increasing volume of heat-treated 
wood produced annually [2]. Thermal modification of wood is a process that involves exposing the material to a temperature between 100 and $300{ }^{\circ} \mathrm{C}$ for periods from $15 \mathrm{~min}$ to $24 \mathrm{~h}$. Depending on the treatment cycle, it is possible to obtain different characteristics in the treated materials. For example, the purpose of the treatment may be to soften the wood, using heat and steam, to release internal tension and facilitate subsequent manufacturing processes; or to achieve controlled degradation of the material to improve dimensional stability and durability. For this purpose, the temperature range is generally between 150 and $260^{\circ} \mathrm{C}$ [2]. Thermal modifications of wood are performed at temperatures between 180 and $260^{\circ} \mathrm{C}$; no significant variation of the material properties occurs at temperatures below $140{ }^{\circ} \mathrm{C}[3,4]$, while exceeding $260^{\circ} \mathrm{C}$ excessive degradation occurs. Modification cycles with temperature over $300^{\circ} \mathrm{C}$ make no sense for excessive degradation of the material [5]. The improved durability of heat-treated wood makes it suitable for outdoor use, where greater exposure to moisture generally contributes to more rapid alteration of the material, so reducing water affinity is an advantage. In fact, heat-treated wood is widely used as a building material, including ayous, especially for the construction of building cladding and exterior flooring. Previous studies have evaluated the moisture behaviour of heattreated wood used for building facades, concluding that heat-treated wood performs better than untreated wood [6,7]. In the literature, however, few works are still available on heat-treated ayous, a wood that is not very durable in its natural state [8,9]. To date, studies conducted on the subject are limited to the analysis of the chemical composition of wood and the analysis with dynamic methods of the mechanical properties of samples subjected to different cycles of heat treatment [10]; on the study of the physical properties of ayous wood subjected to heat treatment with boiling oil by analysing the effect of the treatment on wood hygroscopicity, stability and colour [11]; and on the water resistance of the mechanical properties of joints made of heat-treated wood [12].

Thermally modified wood is a non-biocidal alternative to the classical techniques of extending the natural durability of wood [13] and an effective product with better behaviour in outdoors than natural wood due to a better dimensional stability [6].

Despite market interest, too little is known about natural ayous wood and even less about its characteristics after heat treatment. This study aims to present the first set of data discussed at the First International Electronic Conference on Forests-IECF 2020-[14], allowing the evaluation of industrially thermally modified ayous wood (Triplochiton scleroxylon $\mathrm{K}$. Schum) to highlight the influence of heat treatment at $215^{\circ} \mathrm{C}$ on the selected physical and mechanical characteristics; to add further data and make a comparison with untreated wood from the same area (Cameroon); and to report the results published by other authors to compare the results obtained with the data literature.

\section{Materials and Methods}

The ayous (Triplochiton scleroxylon $\mathrm{K}$. Schum) planks derive from timber taken in a natural forest, FSC (Forest Stewardship Council) certified for forest management and chain of custody, from Cameroon Department of Boumba et Ngoko. The thermal treatment was industrially performed on ayous planks in an autoclave (Model TVS 6000 WDE Maspell srl, Terni, Italy) at a treatment temperature of $215^{\circ} \mathrm{C}$ for three hours with a slight initial vacuum.

The samples were prepared according to the general requirements of the standard for physical and mechanical tests [15] and preserved at laboratory conditions at $65 \%$ relative humidity and $20^{\circ} \mathrm{C}$. Moisture content was determined according to the standard UNI ISO 13061-1 [16]. A ventilated oven was used at $103 \pm 2{ }^{\circ} \mathrm{C}$ for $24+6 \mathrm{~h}$ until the mass was constant. The properties were assessed at a moisture content of $12 \%$ when required, for comparison with literature data. The property adjustment was carried out by placing the samples, before each test, inside a conditioning chamber for $168 \mathrm{~h}$ (or in any case, when the moisture content of $12 \% \pm 0.3 \%$ was reached). This operation was necessary because the correction factor $(\alpha)$ used for normal wood is not applicable to heat-treated wood (result assessed after some preliminary tests). In this sense, further research is underway in order to formulate $\alpha$ suitable for this type of wood. 
Sample dimensions were measured with a digital caliper $( \pm 0.01 \mathrm{~mm})$, and the mass was recorded at a precision scale $\pm 0.001 \mathrm{~g}$. Demineralized water was used to reach the maximum swelling.

The basic and dry densities were calculated on a set of specimens $(20 \times 20 \times 30) \mathrm{mm}$ according to UNI ISO 13061-2 [17]. The tangential, radial, and volumetric shrinkage were determined by considering the total dimensional change from the fully swollen to the oven-dry condition, according to the reference standard ISO 13061-13 and 14 [18]. The shrinkage anisotropy factor was calculated as the ratio between tangential shrinkage and radial shrinkage [19], and the anti-shrink efficiency (ASE) was determined for volumetric shrinkage and cross-section shrinkage using the following formula:

$$
\mathrm{ASE}=\frac{\beta_{\max }-\beta_{\min }}{\beta_{\max }} \times 100
$$

where:

$\beta_{\max }$ is the shrinkage of untreated wood in percent;

$\beta_{\min }$ is the shrinkage of heat-treated wood in percent.

The cross-section shrinkage in percent was calculated using the following formula:

$$
\beta_{\mathrm{cs}}=\left[1-\left(1-\frac{\beta_{\mathrm{t}}}{100}\right) \times\left(1-\frac{\beta_{\mathrm{r}}}{100}\right)\right] \times 100
$$

where:

$\beta_{\mathrm{cs}}$ is the cross-section shrinkage in percent;

$\beta_{\mathrm{t}}$ is the tangential direction shrinkage;

$\beta_{\mathrm{r}}$ is the radial direction shrinkage.

A reflectance spectrophotometer X-Rite CA 22 (X-Rite Inc., MI, USA) was used to quantitatively characterise the colour in the CIELAB colour system. The characteristics of the instrument are as follows: colour scale CIEL ${ }^{*} \mathrm{a}^{*} \mathrm{~b}^{*}$; illuminant D65; standard observer $10^{\circ}$; geometry of measurement $45^{\circ} / 0^{\circ}$; spectral range $400-700 \mathrm{~nm}$; spectral resolution $10 \mathrm{~nm}$; measurement diameter $4 \mathrm{~mm}$; and white reference supplied with the instrument. 60 points were selected to consider the variability of the wood colour, as already discussed [20]. For each point, three measures were made; so, 180 measures were collected. To obtain the colour difference, a comparison was performed with natural wood. The differences in lightness $\left(\mathrm{L}^{*}\right)$, chromatic coordinates $\left(\mathrm{a}^{*}\right.$ and $\left.\mathrm{b}^{*}\right)$, and the total colour difference $\left(\Delta \mathrm{E}^{*}\right)$ were then calculated using these parameters according to UNI EN-15886 [21], as previously described [22]. The "** designates the lightness and colorimetric parameters in the CIELab colour space [21].

Mechanical tests, axial compression strength, static bending strength, and Brinell hardness were performed at the equilibrium moisture content (EMC) of the laboratory conditions and then adjusted at moisture content $12 \%$, when required.

The ultimate axial compression strength was determined following the reference standard UNI ISO 3787 [23] on a set of specimens $(20 \times 20 \times 30) \mathrm{mm}$. The load reached the maximum axial compression strength in 1.5 to 2 min.

The standard ISO 13061-3 [24] was applied to determine the ultimate tensile strength in static bending on a set of specimens $(20 \times 20 \times 300) \mathrm{mm}$. The test was carried out with a span of $260 \mathrm{~mm}$, and the transverse load was applied at mid-span to the radial surface of the specimens; width and height were measured at mid-span with $0.01 \mathrm{~mm}$ of tolerance. The test piece was broken in 1.5-2 min from the start of the applied load.

The resistance to indentation, formerly Brinell hardness, was quantified by UNI EN 1534 [25] on a set of specimens $(50 \times 300 \times 20) \mathrm{mm}$. The maximum load of $1 \mathrm{kN}$ was reached in $15 \mathrm{~s}$ from the start and maintained for $25 \mathrm{~s}$. Two diameters of the residual indentation were measured: one parallel to the fibre direction and the other perpendicular to the fibre direction, at least three minutes after load application. 
Statistical analyses were carried out with StatisticaTM version 7.1 (TIBCO Software Inc., Palo Alto, CA, USA). Data distribution was plotted and checked for normality and homogeneity of variance using the Lilliefors and Levene tests, respectively. To check differences between treatments, $\mathrm{t}$-test for independent samples was applied to assess possible differences among the data of this study and those of a specific research on untreated ayous wood $[14,26]$ originating from the same wood macro sample. Non-linear regression analysis was conducted for all the mechanical variables in relation to the wood density.

\section{Results}

\subsection{Physical Properties}

Table 1 provides an overview of the data from the physical characterization of heattreated ayous wood. The density of this material, referred to as $12 \%$ moisture content, was $0.33 \pm 0.02 \mathrm{~g} / \mathrm{cm}^{3}$, while in anhydrous condition, it was $0.31 \pm 0.02 \mathrm{~g} / \mathrm{cm}^{3}$. The obtained value of basic density was $0.30 \pm 0.02 \mathrm{~g} / \mathrm{cm}^{3}$. The linear shrinkages were $1.27 \pm 0.26 \%$ in the radial direction, and $1.92 \pm 0.25 \%$ in the tangential direction. The observed volumetric shrinkage was equal to $3.16 \pm 0.44 \%$, and the cross-section shrinkage was $1.89 \pm 0.24 \%$. The shrinkage anisotropy factor was 1.55 . The percentage of reduction in the physical properties between treated and untreated wood was $15 \%$ and $11 \%$, respectively. The density was at a moisture content of $12 \%$ and in anhydrous state, $9 \%$ for basic density. In shrinkages, the reduction was $55 \%, 62 \%, 59 \%$, and $61 \%$, respectively, for radial, tangential, volumetric, and cross-section shrinkage. The reduction of the shrinkage anisotropy factor was $15 \%[14,26]$.

Table 1. Physical properties of heat-treated ayous wood.

\begin{tabular}{cccc}
\hline Properties & Samples N. & Mean Value & St. Dev. \\
\hline Density $12 \% \mathrm{MC}\left(\mathrm{g} / \mathrm{cm}^{3}\right)$ & 30 & 0.33 & 0.02 \\
Dry density $\left(\mathrm{g} / \mathrm{cm}^{3}\right)$ & 30 & 0.31 & 0.02 \\
Basic density $\left(\mathrm{g} / \mathrm{cm}^{3}\right)$ & 30 & 0.30 & 0.02 \\
Radial shrinkage $\beta \mathrm{r}(\%)$ & 30 & 1.27 & 0.26 \\
Tangential shrinkage $\beta \mathrm{t}(\%)$ & 30 & 1.92 & 0.25 \\
Axial shrinkage $\beta \mathrm{a}(\%)$ & 30 & 0.16 & 0.07 \\
Volumetric shrinkage $\beta \mathrm{v}(\%)$ & 30 & 3.16 & 0.44 \\
Cross-section shrinkage $\beta \mathrm{cs}(\%)$ & 30 & 1.89 & 0.24 \\
Shrinkage anisotropy factor & 30 & 1.55 & 0.27 \\
\hline
\end{tabular}

$\overline{\mathrm{MC}}=$ moisture content.

Regarding the anti-shrinkage efficiency (ASE) of heat-treated ayous wood, Table 2 summarises the obtained results. ASE referred to as volumetric shrinkage was $58.41 \pm 5.86 \%$, while ASE referred to as the cross-section was $61.01 \pm 4.82 \%$.

Table 2. Anti-Shrinkage Efficiency (ASE) of heat-treated ayous wood referred to as volumetric and cross-section shrinkage.

\begin{tabular}{cccc}
\hline ASE (\%) & Samples N. & Mean Value & St. Dev. \\
\hline Volumetric & 30 & 58.41 & 5.86 \\
Cross-section & 30 & 61.01 & 4.82 \\
\hline
\end{tabular}

\subsection{Colour}

Ayous wood is an undifferentiated wood and in its natural state has a light colour, often described as yellowish or creamy [27-29]. This nonobjective representation is better described in the CIELAB colour space, in which this wood has a lightness of just over 70, with a yellow component due to the colorimetric parameter $b^{*}$ near to 28 , higher than the component $\mathrm{a}^{*}$, which concerns the component that gives the reddish perception [26]. Heat treatment induced a notability darker colouring throughout the entire thickness of the assortment (Table 3). The percentage variation of these parameters between untreated and 
heat-treated wood was much greater in $L^{*}$ and $a^{*}$ (45\% and $43 \%$ respectively) than in the $b^{*}$ parameter $(33 \%)$.

Table 3. Lightness and colorimetric parameters in CIELAB colour space.

\begin{tabular}{ccccc}
\hline & Sampling Point ${ }^{\mathbf{1}} \mathbf{N}$. & $\mathbf{L}^{*}$ & $\mathbf{a}^{*}$ & $\mathbf{b}^{*}$ \\
\hline Mean value & 60 & 39.69 & 10.59 & 18.73 \\
Standard deviation & 60 & 1.13 & 0.81 & 1.51 \\
\hline
\end{tabular}

${ }^{1}$ Note that three measures were made in each sampling point, 180 measures were collected.

However, hue (colour in colloquial terms) is defined by the variation of the parameters $\mathrm{a}^{*}$ and $\mathrm{b}^{*}$, which in our case indicated a substantial increase in the red component $\left(\mathrm{a}^{*}\right)$ and a decrease in the yellow component $\left(b^{*}\right)$ (Table 4$)$. Although the colour change was in this case easily appreciable to the naked eye, the colorimetric parameter that unequivocally indicated the darkening was the colorimetric difference $\Delta \mathrm{E}^{*}$ (Table 4).

Table 4. Lightness and chromatic parameters variation due to industrial heat treatment.

\begin{tabular}{cccc}
\hline$\Delta \mathbf{L}^{*}$ & $\Delta \mathbf{a}^{*}$ & $\Delta \mathbf{b}^{*}$ & $\Delta \mathbf{E}^{*}$ \\
\hline-33.38 & 3.19 & -9.15 & 34.76 \\
\hline
\end{tabular}

\subsection{Mechanical Properties}

The results of these tests were presented in Table 5. The mechanical characterisation of heat-treated ayous wood showed a compression strength parallel to the grain equal to $26.98 \pm 1.99 \mathrm{MPa}$. The ultimate strength in static bending was equal to $32.90 \pm 3.09 \mathrm{MPa}$; and the Brinell hardness was $8.30 \pm 1.05 \mathrm{~N} / \mathrm{mm}^{2}$. The reported values for compression strength parallel to grain and ultimate strength in static bending were both referred to $12 \%$ of moisture content. The percentage of reduction of the mechanical properties between untreated and heat-treated ayous wood were $26 \%$ in compression strength, $46 \%$ in static bending strength, and 32\% in Brinell hardness [14,26].

Table 5. Mechanical properties of heat-treated ayous wood.

\begin{tabular}{cccc}
\hline Properties & Samples N. & Mean Value & St. Dev. \\
\hline Compression strength 12\% MC (MPa) & 35 & 26.98 & 1.99 \\
Static bending strength 12\% MC (MPa) & 40 & 32.90 & 3.09 \\
Brinell hardness (N/mm ${ }^{2}$ & 68 & 8.30 & 1.05 \\
\hline
\end{tabular}

Regarding the relation of the mechanical characteristics with wood density, the results of the regression analysis did not show statistical significance $(p$-value $>0.05)$ and the $\mathrm{R}^{2}$ values were very low $(<0.1)$, except for the compression strength. Figure 1 shows the correlation between compression strength parallel to grain and wood density. Even if, as stated above, the regression analysis did not show statistical significance, there is a positive correlation between these parameters and in this specific case, the $\mathrm{R}^{2}$ value could be considered appreciable at 0.517 . 


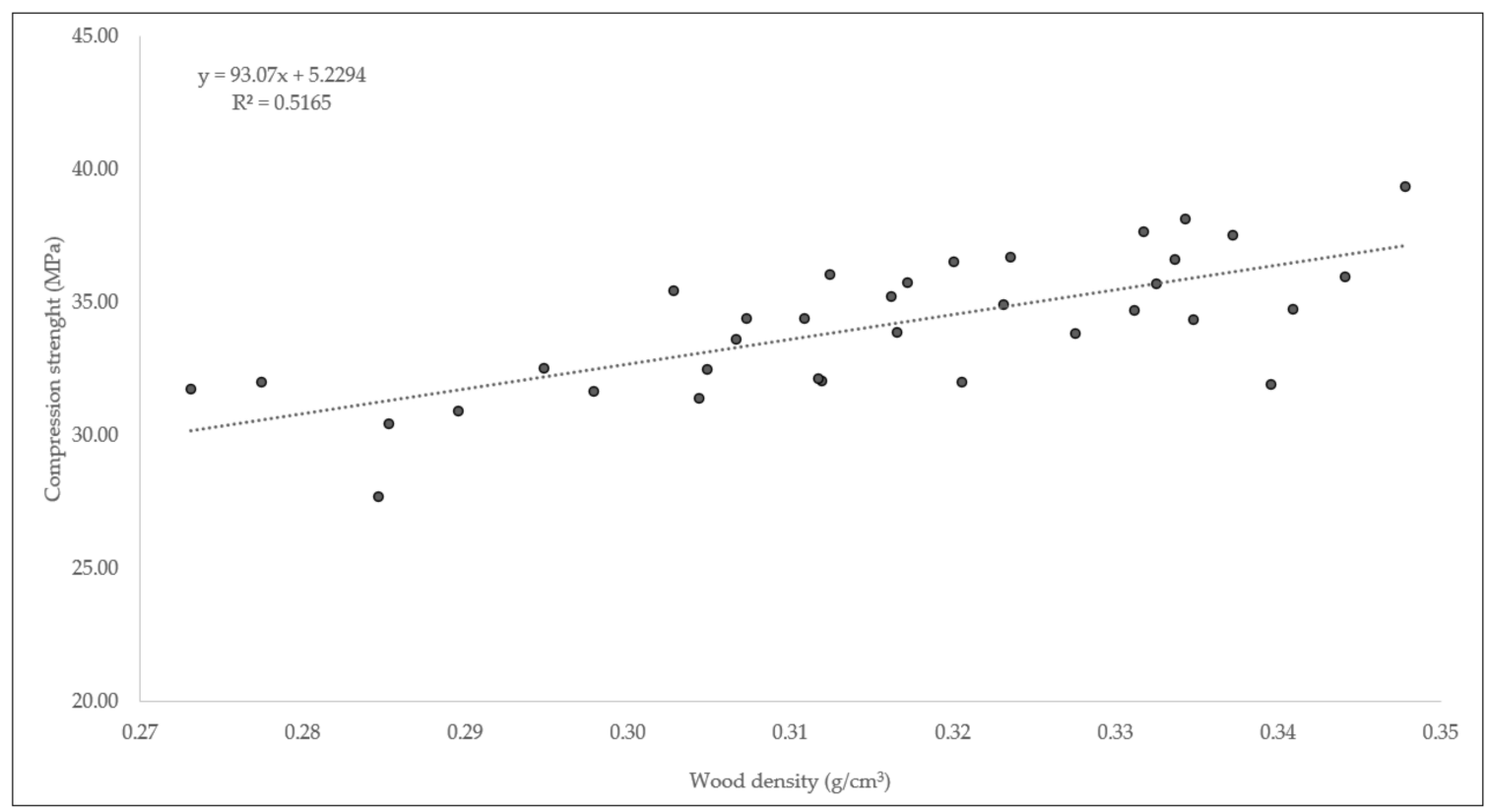

Figure 1. Compression strength of heat-treated ayous wood in function of density referred to MC $12 \%$.

\subsection{Comparison with Untreated Ayous Wood}

Industrial heat treatment statistically significantly modified both the physical and mechanical properties of ayous wood when compared to natural wood [14,26] (Table 6).

Table 6. $T$-test for independent sample results, for physical and mechanical properties, compared between heat-treated wood and normal wood [14,26].

\begin{tabular}{cc}
\hline Parameter & $p$-Value \\
\hline Density 12\% MC & $<0.001$ \\
Basic density & $<0.001$ \\
Radial shrinkage $\beta \mathrm{r}$ & $<0.001$ \\
Tangential shrinkage $\beta \mathrm{t}$ & $<0.001$ \\
Volumetric shrinkage $\beta \mathrm{v}$ & $<0.001$ \\
Compression strength & $<0.001$ \\
Static bending strength & $<0.001$ \\
Brinell hardness & $<0.001$ \\
\hline
\end{tabular}

All the characteristics showed a decrease ranged between $8.2 \%$ and $61.6 \%$ (Figure 2) with high statistical significance. 


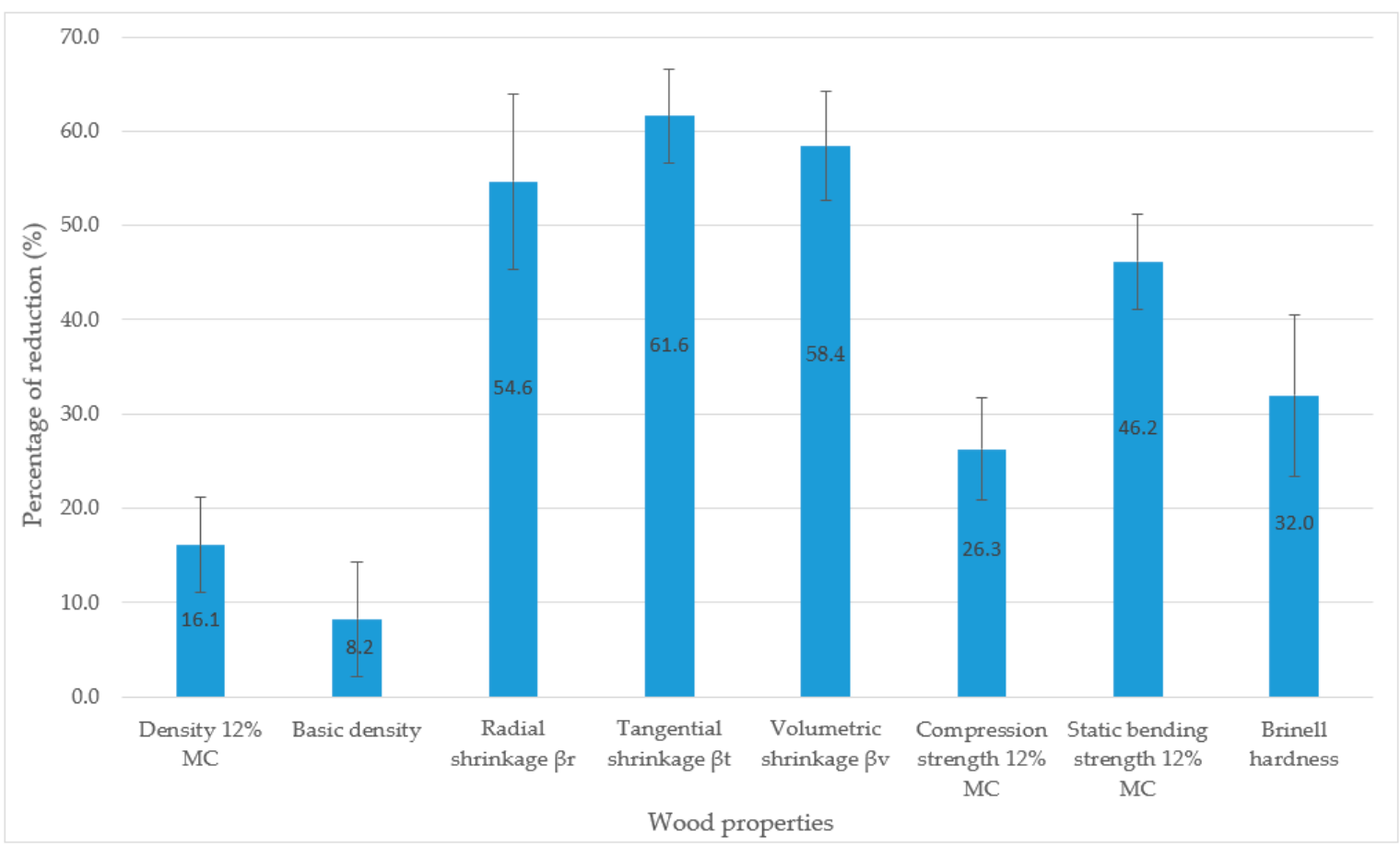

Figure 2. Percentage of variation (reduction) of the mean values, for the heat-treated wood with respect to the normal wood [14,26]. The bars showed the standard deviation.

\section{Discussion}

The consequences of heat treatment on ayous planks affected the mechanical and physical properties of the wood, producing a statistically significant reduction in strength, shrinkage, and swelling, as well as in densities. The mechanical properties generally showed a reduction between 10 and $50 \%$ after the thermal modification; on the other hand, for physical properties, the most important consequences are related to the alteration of the material behaviour with moisture and water. Heat treatment has exacerbated the position of ayous wood among light-density timbers. The reported density values make heat-treated ayous a medium-low density wood material.

One of the main effects of the thermal modification on the physical properties of the wood is related to the behaviour towards water. As a consequence of the treatment, the shrinkage values were rather low, indicating an appreciable dimensional stability of the material, also expressed by the shrinkage anisotropy factor, which was close to that of the wood of species considered to have a low propensity to shape modification [19]. The anti-shrinkage efficiency (ASE) also confirms this improvement; however, the ASE results, referred as to volumetric and cross-section shrinkage, are both lower than $75 \%$, which is considered a threshold in terms of treatment effectiveness for improving the dimensional stability of the material. Reducing the water reactivity of wood leads to improved dimensional stability due to a reduction in swelling; it also leads to a reduction in equilibrium moisture content and, consequently, wood density. Given the effects of moisture as a decay factor in wood, the consequences induced by heat treatment cause an overall increase in the service life of the material [13].

Colour is often a decisive element as it influences the aesthetic of products [30,31]. The effect of heat treatment on wood colour consisted of darkening. The darkening, clearly visible even to the naked eye, was supported almost equally by both the lightness parameter $\left(\mathrm{L}^{*}\right)$ and the $\mathrm{a}^{*}$ parameter, which indicates the red component of the CIELAB colour space. Our eye begins to perceive colour differences with $\Delta \mathrm{E}^{*}$ greater than three, therefore, the value obtained indicated a considerable variation. This empirical observation was confirmed by the chromatic coordinates' values. Lightness of treated ayous was recorded to be like that found in chestnut thermally treated at $200{ }^{\circ} \mathrm{C}$ [4]. The wood colour 
is determined by its chemical components and the colour variation indicates chemical modifications [32-34]. In fact, the products of lignin degradation, including phenolic substances and quinones, contribute to the darkening of wood [35,36].

As expected, the mechanical properties of the heat-treated wood showed low values. These findings confirm those of earlier studies, where a general reduction of the mechanical properties was described after the thermal modification of wood obtained from other species [5,37]. This trend was highlighted in the comparison with untreated ayous wood.

In detail, the shrinkages were the features' high percentage of reduction, and these wood characteristics were then improved, while the other wood features analysed showed modest percentages of reduction but with a completely opposite meaning: these wood characteristics were negatively affected by heat treatment.

The explanation for the change in physical, colorimetric, and mechanical characteristics induced by heat treatment is related to the chemical modification of the molecular components of the cell wall. As Tjeerdsma et al. [36] observed, the chemical composition of wood after heat treatment is mainly related to the thermal degradation of hemicelluloses, which initially leads to the formation of acetic acid, which in turn catalyses the degradation of carbohydrates into simple molecules. Generally, there is also an increase in lignin content, this is due to both the apparent increase in lignin content related to the loss of other components subject to more rapid degradation caused by heat, but also, as reported by Tjeerdsma et al. [36], to the self-condensation phenomenon of lignin that is thought to occur due to the formation of methylene bridges connecting aromatic rings of various organic compounds to some lignin molecules that have available reactive sites [36]. The degradation of hemicelluloses occurs as soon as the temperature reaches $180-200{ }^{\circ} \mathrm{C}$, earlier and faster than cellulose because of their lower molecular weight and amorphous structure [38]; even the amorphous regions of cellulose are structurally modified, obtaining less hygroscopic compounds, while crystalline cellulose is less affected by the changes related to heat treatment up to $300{ }^{\circ} \mathrm{C}[37,39]$. In addition, the reduction of hygroscopicity is also related to the formation of lignin-carbohydrate compounds induced by the exposure to high temperature. This leads to the surrounding of the cellulose microfibrils by a network of more rigid compounds reducing their expansion possibilities and, as a consequence, their absorption capacity. This results in reduced cell wall swelling and lower fibre saturation point of the wood [36]. Another effect of heat treatment, as reported by [40], is the improvement of the wood permeability that allows a better penetration of polar and nonpolar compounds into the texture of the wood. This phenomenon is related to the reduction of the wettability of the material, due to the lower availability of free polar sites on the cell wall compounds, and this can increase the permeability of both water-based and oil-based preservative compounds, which can contribute to a further improvement of the material durability [40].

\section{Conclusions}

In this study, the modifications induced on the mechanical, physical, and colorimetric characteristics were evaluated. Statistically significant differences were found in physical and mechanical properties. The heat treatment resulted in a reduction in compression strength (26.98 $\pm 1.99 \mathrm{MPa})$ of $26 \%$, static bending strength (32.90 $\pm 3.09 \mathrm{MPa})$ of $46 \%$, and Brinell hardness $\left(8.30 \pm 1.05 \mathrm{~N} / \mathrm{mm}^{2}\right)$ of $32 \%$. A light ayous wood was confirmed since dry density was found to be $0.31 \pm 0.02 \mathrm{~g} / \mathrm{cm}^{3}$. The densities were reduced between $15 \%$ and $9 \%$. The positive effect of heat treatment was detected in shrinkage and swelling. Shrinkages were rather low and ayous showed an appreciable dimensional stability, also expressed by the shrinkage anisotropy factor (1.55), and the anti-shrinkage efficiency $(58.41 \pm 5.86)$. The darkening $\left(\Delta \mathrm{E}^{*} 34.76\right)$ was clearly detected $\left(\mathrm{L}^{*} 39.69 \pm 1.13\right.$; $\left.a^{*} 10.59 \pm 081 ; b^{*} 18.73 \pm 1.51\right)$, and it was supported almost equally by both the lightness parameter $\left(\mathrm{L}^{*}\right)$ and the $\mathrm{a}^{*}$ chromatic parameter.

The rapid growth and easy processing of Triplochiton scleroxylon wood has made this species increasingly attractive on the international market. A serious concern for outdoor 
use is its poor durability, and heat treatment can be a processing method that allows ayous wood to improve its stability, durability, and prolong its service life, with reduced environmental impact in service, and after dismantling.

Author Contributions: Conceptualization, A.L.M. and R.P.; methodology, A.L.M., R.P., and E.G.; validation, A.L.M., E.G., and R.P.; formal analysis, A.L.M.; investigation, A.L.M., R.P., and E.G.; resources, A.L.M.; data curation, A.L.M., R.P., and E.G.; writing-original draft preparation, A.L.M., E.G.; writing-review and editing, A.L.M., R.P., and E.G.; visualization, E.G.; supervision, A.L.M.; project administration, A.L.M.; funding acquisition, A.L.M. and R.P. All authors have read and agreed to the published version of the manuscript.

Funding: This research did not receive any specific grant.

Acknowledgments: Authors are grateful to Vasto Legno spa, who donated the industrially heattreated and untreated wooden planks, used in this study. This work was supported by the Italian Ministry for education, University and Research (MIUR) for financial support (Law 232/2016, Italian University Departments of excellence)-UNITUS -DAFNE WP3 and WP4 (Rodolfo Picchio and Angela Lo Monaco) and for basic research activities of Angela Lo Monaco.

Conflicts of Interest: The authors declare no conflict of interest. The funders had no role in the design of the study; in the collection, analyses, or interpretation of data; in the writing of the manuscript, or in the decision to publish the results.

\section{References}

1. Höglmeier, K.; Steubing, B.; Weber-Blaschke, G.; Richter, K. LCA-based optimization of wood utilization under special consideration of a cascading use of wood. J. Environ. Manag. 2015, 152, 158-170. [CrossRef]

2. Jones, D.; Sandberg, D.; Goli, G.; Todaro, L. Wood Modification in Europe: A State-of-the-Art about Processes, Products and Applications; Firenze University Press: Firenze, Italy, 2019.

3. Esteves, B.M.; Pereira, H.M. Wood modification by heat treatment: A review. BioResource 2009, 4, 370-404. [CrossRef]

4. Lo Monaco, A.; Pelosi, C.; Agresti, G.; Picchio, R.; Rubino, G. Influence of thermal treatment on selected properties of chestnut wood and full range of its visual features. Drewno 2020, 63, 1-20.

5. Hill, C.A.S. Wood Modification: Chemical, Thermal and Other Processes; John Wiley and Sons, Ltd.: Chichester, UK, 2006.

6. Humar, M.; Lesar, B.; Kržišnik, D. Moisture Performance of Façade Elements Made of Thermally Modified Norway Spruce Wood. Forests 2020, 11, 348. [CrossRef]

7. Alao, P.; Visnapuu, K.; Kallakas, H.; Poltimäe, T.; Kers, J. Natural Weathering of Bio-Based Façade Materials. Forests 2020, 11, 642. [CrossRef]

8. Scheffer, T.C.; Morrell, J.J. Natural Durability of Wood: A Worldwide Checklist of Species. Forest Research Laboratory; Oregon State University; Research Contribution: Corvallis, OR, USA, 1998; Volume 22, p. 58.

9. Kukachka, B.F. Characteristics of Some Imported Woods. Foreign Wood; Series Report 2242; USDA Forest Service, Forest Products Laboratory: Madison, WI, USA, 1962.

10. Fabiyi, J.S.; Ogunleye, B.M. Mid-infrared spectroscopy and dynamic mechanical analysis of heat-treated obeche (Triplochiton scleroxylon) wood. Maderas-Cienc. Tecnol. 2015, 17, 5-16. [CrossRef]

11. Fotsing, J.A.M.; Fokoua, A.D.S. Effects of thermal modification by the hot oil treatment process on some physical properties of two Cameroonian hardwood species. Int. J. Heat. Technol. 2012, 30, 43-50. [CrossRef]

12. Zor, M. Water Resistance of Heat-treated Welded Iroko, Ash, Tulip, and Ayous Wood. BioResources 2020, 15, $9584-9595$.

13. Kamdem, D.P.; Pizzi, A.; Jermannaud, A. Durability of heat-treated wood. Wood Raw Mater. 2002, 60. [CrossRef]

14. Gennari, E.; Picchio, R.; Tocci, D.; Lo Monaco, A. Modifications of Physical and Mechanical Characteristics Induced by Heat Treatment: Case Study on Ayous Wood (Triplochiton scleroxylon K. Schum). Environ. Sci. Proc. 2021, 3, 27. [CrossRef]

15. International Organization for Standardization. ISO 3129 Wood-Sampling Methods and General Requirements for Physical and Mechanical Testing of Small Clear Wood Specimens; International Organization for Standardization: Geneve, Switzerland, 2019.

16. Ente Nazionale Italiano di Unificazione. UNI ISO 13061-1 Physical and Mechanical Properties of Wood-Test Methods for Small Clear Wood Specimens Determination of Moisture Content for Physical and Mechanical Tests; Ente Nazionale Italiano di Unificazione: Milano, Italy, 2017.

17. Ente Nazionale Italiano di Unificazione. UNI ISO 13061-2 Physical and Mechanical Properties of Wood-Test Methods for Small Clear Wood Specimens Determination of Density for Physical and Mechanical Tests; Ente Nazionale Italiano di Unificazione: Milano, Italy, 2017.

18. International Organization for Standardization. ISO 13061-14 Physical and Mechanical Properties of Wood-Test Methods for Small Clear Wood Specimens Determination of Volumetric Shrinkage; International Organization for Standardization: Geneve, Switzerland, 2016.

19. Ferreira, R.C.; Monaco, A.L.; Picchio, R.; Schirone, A.; Vessella, F.; Schirone, B. Wood anatomy and technological properties of an endangered species: Picconia azorica (Oleaceae). IAWA J. 2012, 33, 375-390. [CrossRef] 
20. Lo Monaco, A.; Marabelli, M.; Pelosi, C.; Picchio, R. Color measurements of surfaces to evaluate the restoration materials. In O3A: Proc Spie; Pezzati, L., Salimbeni, R., Eds.; SPIE: Washington, DC, USA, 2011; Volume 8084, pp. 1-14.

21. Ente Nazionale Italiano di Unificazione. UNI-EN-15886. Conservation of Cultural Property-Test Methods—Colour Measurement of Surfaces; Ente Nazionale Italiano di Unificazione: Milano, Italy, 2010.

22. Lo Monaco, A.; Todaro, L.; Sarlatto, M.; Spina, R.; Calienno, L.; Picchio, R. Effect of moisture on physical parameters of timber from Turkey oak (Quercus cerris L.) coppice in Central Italy. For. Stud. China 2011, 13, 276-284. [CrossRef]

23. Ente Nazionale Italiano di Unificazione. UNI ISO 3787 Wood-Test Methods-Determination of Ultimate Stress in Compression Parallel to Grain; Ente Nazionale Italiano di Unificazione: Milano, Italy, 1985.

24. International Organization for Standardization. ISO 13061-3 Determination of Ultimate Tensile Strength in Static Bending-Physical and Mechanical Properties of Wood-Test Methods for Small Clear Wood Specimens; International Organization for Standardization: Geneve, Switzerland, 2014.

25. Ente Nazionale Italiano di Unificazione. UNI EN 1534 Wood Flooring and Parquet-Determination of Resistance to Indentation-Test Method; Ente Nazionale Italiano di Unificazione: Milano, Italy, 2020.

26. Gennari, E.; Picchio, R.; Lo Monaco, A. Physical and Mechanical Properties of Triplochiton scleroxylon K. Schum from Cameroon. Drewno 2021. under review.

27. Giordano, G. Tecnologia del Legno; UTET: Torino, Italy, 1988; Volume 3/II, pp. 1091-1093.

28. Berti, R.N.; Abbate, M.L.E. Legnami Tropicali Importati in Italia: Anatomia ed Identificazione, 1st ed.; Ribera Editore: Milan, Italy, 1988; pp. 200-201.

29. Olorunnisola, A.O. Anatomy and Physical Properties of Tropical Woods, Design of Structural Elements with Tropical Hardwoods; Springer International Publishing: Cham, Switzerland, 2018; Chapter 2; pp. 7-29.

30. Calienno, L.; Pelosi, C.; Picchio, R.; Agresti, G.; Santamaria, U.; Balletti, F.; Lo Monaco, A. Light-induced color changes and chemical modification of treated and untreated chestnut wood surface. Stud. Conserv. 2015, 60, 131-139. [CrossRef]

31. Sedliačiková, M.; Moresová, M.; Aláč, P.; Malá, D. What Is the Supply and Demand for Coloured Wood Products? An Empirical Study in Slovakian Practice. Forests 2021, 12, 530. [CrossRef]

32. Agresti, G.; Bonifazi, G.; Calienno, L.; Capobianco, G.; Lo Monaco, A.; Pelosi, C.; Picchio, R.; Serranti, S. Surface investigation of photo-degraded wood by colour monitoring, infrared spectroscopy and hyperspectral imaging. J. Spectrosc. 2013. [CrossRef]

33. Pelosi, C.; Agresti, G.; Calienno, L.; Lo Monaco, A.; Picchio, R.; Santamaria, U.; Vinciguerra, V. Application of spectroscopic techniques for the study of the surface changes in poplar wood and possible implications in conservation of wooden artefacts. Proc. SPIE 2013, 8790, 1-14.

34. Calienno, L.; Lo Monaco, A.; Pelosi, C.; Picchio, R. Colour and chemical changes on photodegraded beech wood with or without red heartwood. Wood Sci. Technol. 2014, 48. [CrossRef]

35. González-Peña, M.M.; Hale, M.D.C. Colour in thermally modified wood of beech, Norway spruce and Scots pine. I. Colour evolution and colour changes. Holzforschung 2009, 63, 385-393. [CrossRef]

36. Tjeerdsma, B.F.; Boonstra, M.; Pizzi, A.; Tekely, P.; Miliz, H. Characterisation of thermally modified wood: Molecular reasons for wood performance improvement. Wood Raw Mater. 1998, 56, 149-153. [CrossRef]

37. Yildiz, S.; Gezer, E.D.; Yildiz, U.C. Mechanical and chemical behavior of spruce wood modified by heat. Build. Environ. 2006, 41, 1762-1766. [CrossRef]

38. Lewin, M.; Goldstein, I.S. Overview of the chemical composition of wood. In Wood Structure and Composition; Marcel Dekker Inc.: New York, NY, USA, 1991; pp. 1-6.

39. Yildiz, S.; Gümüskaya, E. The effects of thermal modification on crystalline structure of cellulose in soft and hardwood. Build. Environ. 2007, 42, 62-67. [CrossRef]

40. Taghiyari, H.R.; Abbasi, H.; Militz, H.; Papadopoulos, A.N. Fluid Flow of Polar and Less Polar Liquids through Modified Poplar Wood. Forests 2021, 12, 482. [CrossRef] 